\title{
Design as a negotiation platform: new deals and spatial adaptation in flood-prone areas
}

\author{
F. Rossano ${ }^{1}$ \& L. Hobeica ${ }^{2}$ \\ ${ }^{1}$ Institute of Landscape Architecture, \\ Federal Institute of Technology - ETH Zurich, Switzerland \\ ${ }^{2}$ Institute for Interdisciplinary Research, University of Coimbra, Portugal
}

\begin{abstract}
In current measures taken in Europe to cope with growing flood risks, various elements characterize the strategic and practical choices involving anticipation, protection or mitigation. One crucial element in all flood-related projects is space. In quantitative and qualitative aspects, most flood adaptation strategies imply a morphological transformation of city and landscape, as well as the redefinition of land use and status, which in its turn can lead to new deals among territorial players. These multi-scale interplays can eventually put financial, political and social status-quo under unknown pressure, and transform the role of urban and landscape design, which gains in importance but also in complexity. The nine contemporary flood-related projects reviewed reveal that the fluctuating conditions and multiple interests in which they evolve require, in addition to creative approaches, openness, perseverance and diplomatic skills. Landscape, urban or architectural design becomes then an open and dynamic platform for spatial renegotiation and adaptation, challenging design practices in flood-prone areas as well as democratic structures.
\end{abstract}

Keywords: flood risk, urban and landscape design, adapted spatial design, negotiation platform.

\section{Introduction}

Flood-related riverine projects involve two precious resources for urban civilizations: water (the river) and space. In fact, they all imply physical and/or cognitive redefinitions of space: local public space and civil works can become 
regional defence infrastructures; land that seemed suitable for building can become junk bond for investors if declared risk zone; purely agrarian areas can turn into water storage. Along with these transformations, city and landscape negotiate a new potential damage distribution, building up inter-linkages and engaging into a reflexive redefinition of their respective roles. Besides, within the city, riverine spaces generate simultaneously growing fears, waterfront development ambitions and new functional combinations. These multi-scale interplays, the economic and social pressures linked to them, and the diversity of territorial players involved represent an extra layer of complexity in the remit of spatial designers. Yet, some contemporary European flood-related projects do recognize both space and water dynamics as crucial variables of flood adaptation strategies. Our methodological approach was thus to review nine of these projects, aiming to identify how spatial design has fulfilled its task of negotiation platform. Case study was adopted as the research method, as it allows to gain a comprehensive view of the targeted projects, thanks to its simultaneous attention to "the complex relationships between context, product and process that govern every design process" [1].

After introducing an overview of the multiple stakes involved in most flood adaptation strategies (Section 2), the paper will pinpoint to how the notion of 'river space' has taken spatial design as a new dimension of flood management (Section 3), implying for flood-prone territories a $\mathrm{New}$ Deal generated by design (Section 4). We will then summarize some of the main roles played by spatial design (acting as a dynamic negotiation platform) to shape these new deals in the analysed cases (Section 5), before concluding with general implications and prospects for future developments in flood-prone territories.

\section{Flood proneness: one among several territorial constraints}

Coping with riverine flood risk usually involves multiple conflicts, despite the overall characteristic of the river or the territorial scope of the adaptation alternatives. When embedded in the urban scale, a first dilemma can be accepting the very existence of flood risk in this setting, a well-known cognitive conflict. In fact, the lives of urban dwellers are increasingly disconnected from natural variations, and people living in flood-prone zones, through a heuristic mechanism, tend to perceive their homes as inherently safe places [2]. Despite the concentration and value of assets exposed to floods in cities, this risk is usually made invisible by the existence of structural flood defences, which promote (or at least do not discourage) a less precautious attitude towards flood proneness. This is even more blatant when urban regeneration or development is at stake. Here, several demand conflicts are added to the perceptive one: shorterterm urban needs (like housing or economic development) tend to exert justifiably, one could argue - high pressure on flood-prone areas, as the experience of everyday problems by local populations is more direct than that of floods, with their extraordinary (but potentially devastating) character [3].

In their turn, other sustainability issues (e.g. urban compactness and mobility) transform traditional "bad places" (floodable, polluted etc.) into valid options for 
urban development [4]. In recognition of such site strengths as location, scenery or existing infrastructure, instead of simply banning redevelopment, some authors advocate a more pragmatic approach (for example Barroca and Hubert [5]), whereby existing site constraints and strengths are weighed against each other, in a more horizontal decision process. In this condition, damages and responsibilities (and also benefits) can be recognized in advance and shared between all stakeholders, in an attempt to maximize gains and minimize regrets. But this is far from a straightforward process; the reality on the ground is much more complex, especially in cases where the best flood adaptation solutions have a regional scope, exceeding usual administrative boundaries and competencies.

As space is the real arena where the conflict between rare hazardous events and more tangible human interests is made visible, designing space has logically to deal with all idiosyncrasies involved in a given river and the wider space around it. Similar baseline conditions can lead to various conflicts and divergent results. For the Scheldt Quays in Antwerp and the Isarplan in Munich, floodplain function and urban life had to be combined into one single design. In Antwerp, the competition brief highlighted (potential) conflicting issues within the design task: raising the flood defence scheme (final height 2.25 metres), not obstructing the city view of the river and eliminating the urban barrier effect of the wall. The selected design proposal finally accommodated these demands by merging them in a single urban "civil-civic structure" [6], which is altogether a levee and a belvedere, and adapts to the site's local circumstances. In Munich, the main goals of the initiative seemed well established by the city and the State of Bavaria, namely combining urban recreation with environmental restoration and a functional hydrological system. However a controversy emerged after the results of the design competition were made public, opposing partisans of an outspoken urban space design and supporters of a nature-like project. The final solution was a compromise that respects infrastructural constraints but suggests natural freedom by creating artificial islands, pebble paths and curved shores (a nature forged by the designer in order to meet the public's aesthetic expectations). In both cases of Antwerp and Munich, spatial design was challenged by conflicting and combinatory expectations, becoming a fundamental dimension of the pursued flood management strategy.

\section{Spatial design: a new dimension to flood management}

\subsection{From river to river space}

Many of the recent flood adaptation projects associate to traditional interventions (such as river bed dredging or levees enforcement) horizontal solutions such as river widening, floodplain restoration or the creation of controlled flood areas. The Netherlands, renowned for its dikes and sea walls, is now implementing the 2,300-million programme Room for the River that consists, among other interventions, in widening rivers in both cities (e.g. the Waal River in Nijmegen) and countryside (e.g. the Merwede River in the Noordwaard area) [7]. The country today officially promotes a "multi-layer safety" approach [8], based on 
three dimensions: flood prevention, sustainable spatial planning and disaster control, which include both mitigation and adaptation measures (such as the so-called 'calamiteitenpolders', agricultural polders that allow temporary flooding to avoid greater damage in urban areas). Comparable expansion and diversion strategies are currently being developed along the Isère River (France) and the upper Rhône Valley (Switzerland).

Although the "space for the river" approach could wrongly be presented as a new concept [9], the increasing interest for horizontal answers to riverine flood risk, together with the growing acceptance of occasional flooding as an inevitable hazard to be dealt with rather than eliminated, logically reinforce the spatial aspect into flood management. Subsequently, contemporary official documents elaborated to communicate on flood adaptation projects often refer to the river not only as a stream but more frequently as a space: Ruimte voor de Rivier (the Netherlands), Isarraum (Bavaria) or Espace Rhône (Swiss Valais), all suggest the necessity to consider not only the stream and its edges, but a wider area that includes all surfaces that can be potentially affected by the river's fluctuations. Furthermore, post-World War II urban densification and sprawl have changed radically the context of flood management. Water retention and flood diversion areas cannot be solely implemented within the natural environment, generally too reduced or fragmented to assume this function; in fact, they compete today with farmland, infrastructure, recreation space, ecological restoration or urbanization. Thus, the expansion of the river space initially meant to accommodate higher discharges and prevent flooding, combined with a strong land shortage within urban areas, calls for an integrative design to blend all parameters into an altogether attractive, ecologically valuable, resourceful and safe living environment. Long seen as infrastructures or threats, rivers and their fluctuations are now by necessity being reintegrated into the public physical and cultural realms, raising new questions in regards to the space needed, its perimeter, status, accessibility and still-to-be-defined aesthetics.

\subsection{A New Deal for flood-prone territories}

Traditional European planning regulations long defined flood zones on the basis of previous events and/or flood models, to then apply limitations in land use and construction. Although still essential to most planning practices, this passive method shows today its limits, especially in densely built flood-prone environments. Numerous constructed obstacles have modified the contours and behaviour of flooding. Contemporary flood zones are thus no longer determined only by natural elements, but increasingly by the effects of man-made civil works, earthworks, buildings or planted vegetation, as a result of past political decisions - if not the sum of faits accomplis. Furthermore, when potential flood space covers all or large parts of the living territory, the question cannot be solved in simple terms of building limitations or natural floodplain restorations, but also involves a crucial negotiating aspect to define what needs to be floodable in order to accommodate higher discharges and to protect the most valuable assets. Permanent river widening, as applied to the upper Rhône River, or the creation of temporary flood spaces, such as the Dutch calamiteitenpolders 
and the French champs d'inondation contrôlée (controlled flood fields) currently implemented along the Isère River, are successful examples of diversion strategies.

Contemporary flood adaptation programmes therefore suppose a notion of acceptable loss of safe ground and often a notion of acceptable damage. These two notions are both dynamic (as they cannot be exactly predefined) and reflexive (as by accepting flooding in certain areas of a land or city, other parts of the territory will be spared). The newly designated 'river space' thus encompasses much more than the surface of the stream, but refers to the necessary space of fluctuation, whose contours are not fixed but rather gradual (from permanent stream, seasonal riverbed, foreshore, retention areas, flood zones); each level of permeability allowing different activities to take place, as long as primary hydraulic functions are guaranteed. In this context, the redefinition, expansion or transformation of flood-prone areas exclude any purely objective, unique and final configuration, but imply complex negotiations, painful arbitrages and dynamic designs to reach optimal risk-safety distribution and land valorisation. In the investigated projects (listed in Table 1), this redefinition resulted in a new territorial deal among owners, users and beneficiaries of the adaptation project, involving both material elements (land and infrastructure) and immaterial ones (value of areas and degree of risk allocated to them), all merged into a new territorial structure. The studied cases have shown that this new deal has clear implications on, among others, the limits of flood-prone areas, land statuses, related rules, as well as on practices of riverine users, as presented below.

Table 1: The nine flood-related projects studied.

\begin{tabular}{|c|l|l|l|l|}
\hline Country & \multicolumn{1}{|c|}{ River } & \multicolumn{1}{|c|}{ Location } & \multicolumn{1}{|c|}{$\begin{array}{c}\text { Flood adaptation } \\
\text { intervention }\end{array}$} & \multicolumn{1}{c|}{ Spatial type } \\
\hline BE & Scheldt & Antwerp & Floodplain expansion & Intra-urban park \\
\hline CH & Rhône & Valais & River widening & Mixed-use valley \\
\hline DE & Isar & Munich, Bavaria & $\begin{array}{l}\text { Floodplain } \\
\text { restructuration }\end{array}$ & Intra-urban park \\
\hline FR & Garonne & Bordeaux & $\begin{array}{l}\text { Floodable urban } \\
\text { development }\end{array}$ & $\begin{array}{l}\text { Intra-urban } \\
\text { development }\end{array}$ \\
\hline FR & Isère & Isère, Rhône-Alpes & Controlled flood fields & Mixed-use valley \\
\hline NL & Eemskanaal & $\begin{array}{l}\text { Groningen, } \\
\text { Meerstad }\end{array}$ & $\begin{array}{l}\text { Emergency retention } \\
\text { lake }\end{array}$ & Peri-urban extension \\
\hline NL & Maas & Overdiepse polder & $\begin{array}{l}\text { High-water floodplain } \\
\text { extension }\end{array}$ & Agricultural polder \\
\hline NL & Merwede & Noordwaard & $\begin{array}{l}\text { High-water diversion } \\
\text { channel }\end{array}$ & $\begin{array}{l}\text { Agricultural polders } \\
\text { and nature area }\end{array}$ \\
\hline PT & Mondego & Coimbra & $\begin{array}{l}\text { Floodplain } \\
\text { consolidation }\end{array}$ & Intra-urban park \\
\hline
\end{tabular}




\section{Design as negotiation platform}

\subsection{New negotiation frameworks}

Contrary to traditional vertical flood protection, adaptive approaches and horizontal interventions often generate strong resistances from land owners and users, as they imply radical changes onto public and private property, and affect the global land-use distribution of the area. In several cases, ontological discussions arose, questioning the legitimacy of each of the competing land uses and, more generally, the priority that society as a whole should give to each of them, opposing productive functions (such as farming) to functions considered unproductive (nature and recreation). A more symbolic dimension plays as well a role in the negotiations: giving back to water a space that has been gained on rivers and marshlands through centuries of land reclamation can be (wrongly) interpreted as a regression from a cultivated or otherwise explored territory to a natural state. Yet, the extensive investigations and technical means needed to implement such spaces show that even the new 'space for the river' is primarily the result of a design intervention [3]. It appears thus difficult but crucial for local authorities to articulate the different scales and terms of the equation in order to install a positive climate for negotiations.

\subsection{New perimeters}

While river space has long been defined as a negative space, progressively reduced to maximize productive areas and expand building lands, the current shift from flood defence to flood adaptation implies a reverse approach that first defines the space needed to accommodate expected high waters, and subsequently seeks to adapt the surrounding areas to provide the needed capacity. Contrarily to the passive definition of flood zones, the definition of adaptive measures, though elaborated with scientific tools, remains in essence a political choice in its spatial translation, which implies a consensus on the principle of the intervention and its perimeter. The interventions decided within the Room for the River programme, located along river courses, were motivated by the raise of national norms for river capacities that followed the 1993-1995 near flooding along the Rhine and Meuse rivers. For each measure, the type of intervention, the financial means and expected effects on water level were set, while the precise definition of river space and flood areas was left to regional and local players, in collaboration with the national water authorities. The definition of the new flood zones within the Noordwaard area and Overdiepse polder eventually incorporated various elements: efficiency in hydrological terms, cost targets, spatial quality, ecological value and sustainability of remaining farms and dwellings. In the Swiss upper Rhône Valley, the decision of widening the riverbed in order to increase its capacity was set by the Canton authorities at the turn of the century, but various options can still be implemented locally, including reinforcing the existing dikes or dredging the river. There again, 
agreeing on the general means and objectives sets a discussion frame, but merely opens the negotiations that will ultimately modify the area where water will be allowed to fluctuate with more or less freedom.

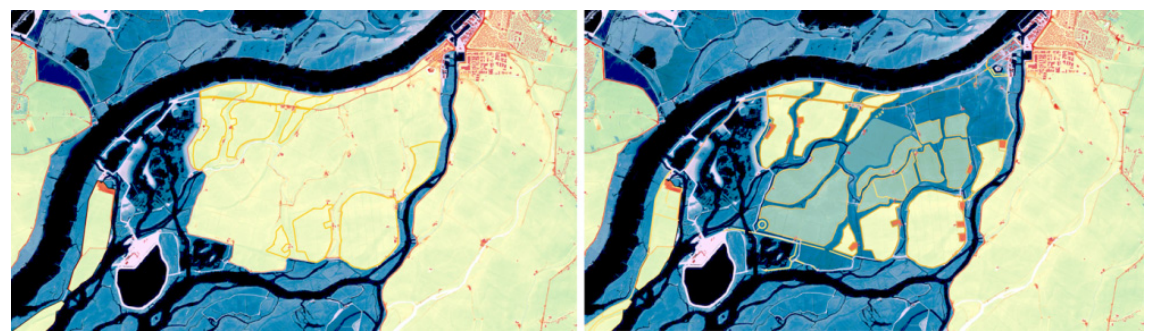

Figure 1: Spatial adaptation in the Noordwaard area - Room for the River, the Netherlands (Rossano).

\subsection{New status}

Territorial flood adaptation implies in most investigated cases a change in land status. This change is not necessarily binary - from protected land to floodable area - but more often combinatory: for example, urban public space embraces river expansion zones (Antwerp, Coimbra), or farmland is used as emergency storage area (Overdiepse polder, Isère Amont). Introducing a flood-related function in a given site often goes with a loss of its value: safety is reduced locally in order to increase in a wider area. In the article "Who likes to live in the calamiteitenpolder", the Dutch newspaper NRC echoed the debate following the proposal of the Luteyn governmental commission to designate several emergency retention polders, where waters from the Meuse and Rhine rivers could be diverted to in case of threatening high waters [10]. House owners complained that their properties had lost in value, even though the proposal was still at an early stage. In the French Isère Valley, opposite protests were heard when regional authorities announced the creation of 16 champs d'inondation contrôlée closed for construction: local representatives saw land prices soar around one of the designated flood zones, threatening municipal housing policies. In both cases, local economies were influenced by the mere eventuality of a status change that would turn (potential) building land into designated flood area.

However, status changes can have positive global effects, and should therefore not only be seen in terms of risk catchers and beneficiaries, but also in terms of combinatory opportunities. For example, farmland used for flood adaptation is itself, by essence, located in a flood-prone area, and can thus benefit from explicit agreements with local authorities. As it appeared to farmers of the Groningen province during the negotiations held with the Water Board, they were actually better off if their land was identified as "emergency polder" and covered by a compensation guarantee, than not insured and still in a flood zone [11]. Cities are not left aside from major status modifications induced by changes in flood adaptation strategy. Open public spaces along the river are then 
the most obvious urban land use to absorb flood adaptation projects. However, status change can also take place in the opposite direction, from flood area to building land within new conditions (Bordeaux), or from restricted floodplain to open public recreation space (Munich), which in its turn increases quality of life and values up the immediate surroundings. However, as the Munich case shows, new status generates new practices, which are not always foreseen, as the new combinatory land uses overlap various regulations and mores. Local authorities welcome the success of the new Isar River space, but simultaneously struggle to control crowds' behaviour in what is altogether a new kind a public park, a nature area and still a floodplain.

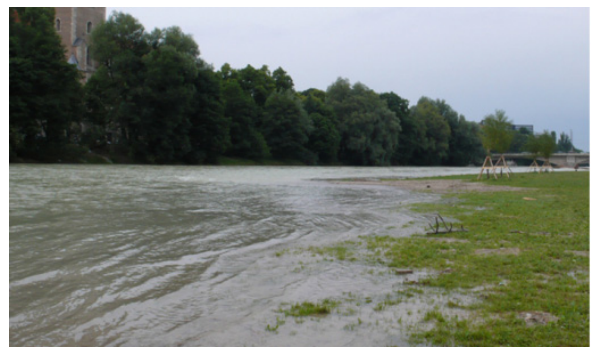

Figure 2: From floodplain to urban beach: Isarraum, Munich, June/September 2013 (Rossano/Kuenzel).

\subsection{New rules and practices}

Flood-prone spaces officially acknowledged as such not only undergo changes in perimeter and status, but also in the way various activities can take place and be regulated, bringing new challenges for local authorities and citizens. The robust and simple design of the Isarplan facilitates the maintenance and post-flood restoration, but also introduces a new freedom within the city, allowing behaviours that are generally banned from historical parks and squares. Vast, informal and less regulated, the flood-prone public spaces offer freedom of use and the thrill of finding oneself in a risk area. The downside of this new freedom, as it appeared there in recent years, is the difficulty to offer basic facilities and to protect ground and vegetation in a space that can host more than 30,000 visitors on a sunny weekend and be covered by high waters a week later. The Isar space is altogether loved for but also victim of its dynamic nature, spatial simplicity and low regulation, illustrating the need for a new balance between control and laisser-faire - for the river and for its visitors. Within the built area, the Bordeaux Brazza case is perhaps the one that better illustrates changing rules, since it is a typical urban regeneration project within a flood-prone zone. Here, land-use regulations were fully reviewed, for example to make possible the conciliation between elevated ground-floors and accessibility for disabled people, or to guarantee that every new building is as much as possible hydraulically transparent. Finally, outside the city, where extreme water discharges are temporarily directed towards farmlands, status change also 
implies new rules and agreements. Once defined as diversion stream or emergency retention area, hydraulic functionality becomes an extra constraint in farming and nature areas, as no obstacles should hinder the expected effects of controlled inundation. Depending on the predicted flood frequency, costly infrastructures such as irrigation systems or glasshouses are to be avoided to limit potential damages, but also uncontrolled vegetation growth that diminishes permeability. Flood adaptation in agricultural areas furthermore brings along new recreational functions, which are not always welcomed by local farmers and dwellers, and need again careful design negotiations to combine recreation, risk and productive activities.

\section{Design roles within flood adaptation}

An adaptive perspective, looking at the territory from the 'point of view' of the river, implies an important shift in the planning process: besides the indispensable knowledge of hydrologists and civil engineers, active investigation into the social, economic and cultural characters of an extensive area is needed, in order to identify in the concerned territory the best adaptation strategy potentially embedded in it. This implies a good understanding of its morphology (seen as the materialization of functions and interests assembled into a dynamic spatial structure), as well as an ability to mentally manipulate this structure and envision transformation possibilities. These abilities, developed in architectural practice, appear useful to address the layered and spatial nature of this territorial adaptive approach. In each negotiation process analysed, the design of the river space has fulfilled various roles. Three rough categories emerged from the collected data so far; their polishing is being pursued while the authors deepen their analyses.

\subsection{Design as eye-opener}

Projects today implemented or under construction show that sketches and practical spatial proposals facilitate the appropriation by local players, even at an early stage of development. In this sense, the process that took place in Sion, the capital city of Valais, is an exemplary illustration. Short after the launch of the Rhône 3 programme, the city's urban planning department made a proposal to commission a design study to investigate potential changes in the city's relation to the river, but this was rejected by the city council, which considered Rhône 3 a strict flood defence project (thus a prerogative of the Canton and not eligible for municipal funding). Yet, both City and Canton welcomed, in 2009, an initiative from the Chair of Landscape Architecture of Prof. C. Girot (ETH Zurich) to organize a landscape design studio on the same theme. With their support, the students' visionary works were shown in an exhibition in Sion, in 2010. Mr. Gross, one of the persons in charge of urbanism within the municipality, recalls that "through the students' projects, we could raise awareness for the potentiality of this project, that it was not just a problem of security but also a formidable opportunity to bring quality to the city along this 
river" [12]. He also stressed that "the exhibition was a success, and people really appropriated the term Sion-sur-Rhône", title given to the design studio and to the following publication [13]. A design competition for the reconfiguration of the public spaces along the Rhône was eventually organized a year later, and is, right now, in the process of further detailing by the winning design team. Although the initial design envisioned by ETH Zurich's students was not literally adopted, it bridged the gap between City and Canton at a crucial moment in the planning process (namely when urban ambition and flood mitigation could be connected for the benefit of both), and it mobilized a population that hitherto had shown no interest in what they saw as an abstract and purely technical issue.

\subsection{Design as clarifier}

The design competition held in Munich for the most central segment of the Isarplan shows how spatial design can reveal latent expectations and oppositions. Differently from the strictly internal process that supported the restoration of the southern part of the river, the project commissioners decided in 2006 to organize a landscape design competition on the Isar segment crossing the city centre. The winning design envisioned a central linear sculptural element separating the main stream and the new recreational open space, acknowledging the existing technical constraints that would make impossible to set the river free. The second prize was awarded to a completely different proposal, with an organic, informal design. Yet, a public quarrel followed, showing that a significant part of the population had expected a more spectacular 'renaturation' project and rejected the urban aspect of the winning design. A period of intense and often emotional discussions followed, involving city, local districts, water board and citizens, giving the opportunity to express wishes and constraints, and eventually leading to a consensual proposal that guaranteed the safety of urban infrastructures and still suggested a certain natural freedom, most wanted inside the city. In the words of the former Head of the city planning department, "it was important to show, on the one hand, how little freedom there is when the river is so important, but, on the other, to speak with people about this limited freedom we have, because people perhaps expected something much more impressive. (...) These competitions were more an education project. It was necessary to communicate" [14]. Through an intense debate that could only have been ignited by concrete proposals, the Isarplan left the secluded world of environmental and technological expertise, on the one hand, and the realm of romantic dreams, on the other. The design was thus not the result of a predefined image, but initiated new perspectives leading to alternative trajectories.

\subsection{Design as matchmaker}

The opening of the design process to a wider panel, in the programmatic phase, offers the opportunity for participants to match more general expectations and possibilities with specific options of spatial configuration. Shared scenarios can then be created through the discussion about the distribution of land and investments, and the elaboration of the envisioned spatial framework and 
physical interventions. This matchmaker role was well illustrated by the process of elaboration of the Meerstad project: during the planning workshops, participants received basic programme elements (represented by on-scale pieces of coloured paper, proportional to the land requested for water, wetlands, woods, housing and industry), and by playing with them onto the area's map, they could quickly elaborate spatial distribution scenarios. Apart from allowing all present players to envision their preferred options, this scenario-based participative approach made them conscious of the difficulty of combining various elements into a legible and attractive spatial framework. The community participation in the design process that took place in the Overdiepse polder was even more radical, as local inhabitants actually anticipated the planning process, right after the area was identified by the government as a suitable floodplain extension. They had to deal with a relatively simple equation (but a sensitive matter), as it was clear that not all 16 existing farms could sustain their activity in the area. They grasped the chance to develop their own plan, with support from the national and regional authorities, choosing the most convenient project from their point of view (the reconfiguration of the whole polder into a temporary expansion space for high waters with nine heightened platforms for the future farms). In this particular case, the design allowed the building of a consensus not only between authorities and farmers, but first of all among local players themselves, who could better deal with the economic and human aspects of the project, and translate them into an agreed and shared framework.

\section{Final considerations}

Territorial design, by nature, is a complex task of organizing multiple collective intentions, uses, desires, possibilities and constraints in a balanced, sensitive and also inspiring spatial arrangement. Yet, when the existing constraint is linked to riverine flood risk, the designers' task is made even more challenging, as the possibility to turn flood proneness into a great spatial opportunity is latently offered. The analysed projects showed that despite all its complexities, the design of flood-prone spaces can be performed as an open negotiation platform. As a dynamic process, design is allowed to evolve: it can take into consideration natural fluctuations as well as ever-changing sociocultural aspects, and can also orchestrate the interdisciplinary approach needed to balance (apparently) concurrent objectives with different time horizons. As an open platform, designing river spaces comprises two complementary characteristics: by fostering a wider participation, it promotes a valuable interchange of inputs between stakeholders and designers, where unforeseen combinatory options can actually emerge. On the other hand, by reintroducing the free will that characterizes the practice of spatial design [15], it facilitates the emergence of collective choices and consensual territorial visions beyond problem solving. Not only this can eventually increase players' sense of project ownership but surely acts as a powerful sensitization tool, bringing flood risk closer to people's daily lives, and helping democratic societies build positive and shared answers to flood risk challenges. 


\section{Acknowledgements}

This study was funded by the Swiss National Science Foundation and the Portuguese Foundation for Science and Technology, through $\mathrm{PhD}$ grants. The authors are thankful to all designers and territorial players who generously provided information to both $\mathrm{PhD}$ researches.

\section{References}

[1] Foqué, R., Building knowledge in architecture. UPA: Brussels, p. 174, 2010.

[2] Harries, T., Feeling secure or being secure? Why it can seem better not to protect yourself against a natural hazard. Health, Risk and Society, 10(5), pp. 479-490, 2008.

[3] Klijn, F., Bruin, D., Hoog, M.C., Jansen, S. \& Sijmons, D.F., Design quality of room-for-the-river measures in the Netherlands: role and assessment of the quality team (Q-team). International Journal of River Basin Management, 11(3), pp. 287-299, 2013.

[4] Viganò, P., Extreme cities and bad places. International Journal of Disaster Risk Science, 3(1), pp. 3-10, 2012.

[5] Barroca, B. \& Hubert, G., Urbaniser les zones inondables, est-ce concevable? Développement Durable et Territoires. http://developpementdurable.revues.org/index7413.html

[6] De Meulder, B. Personal communication, 5 October 2013, Architect/Urbanist, WIT Architecten, Louvain, Belgium.

[7] Ruimte voor de rivier. Samen werken aan een veilig en mooi rivierengebied.

http://www.ruimtevoorderivier.nl/media/78773/corporate brochuredefdoo rlopend.pdf

[8] Ministerie van Verkeer en Waterstaat, Ministerie van Volkshuisvesting, Ruimtelijke Ordening en Milieubeheer, Ministerie van Landbouw, Natuur en Voedselkwaliteit. Nationale Waterplan 2009-2015, pp. 6, 71-73, 2009.

[9] Warner, J., Edelenbos, J. \& van Buuren. A., Making space for the river: governance challenges (Chapter 1). Making space for the river, eds. J. Warner, A. van Buuren \& J. Edelenbos. IWA: London, pp. 1-13, 2012.

[10] Schreuder, A. Wie woont er graag in de calamiteitenpolder?, Rotterdam, 02.12.2002, http://vorige.nrc.nl/binnenland/article1554360.ece

[11] Van Hall, A. Personal communication, 13 March 2013, Dike Master, Water Board Hunze \& Aa's, Veendam, the Netherlands.

[12] Gross, D. Personal communication, 24 July 2013. Municipality Urbanist, Sion, Switzerland.

[13] Girot, C., Rossano, F. \& Duner, I., Sion-sur-Rhône, un nouveau paysage pour la vallée du Rhône à Sion. GTA: Zurich, 2010.

[14] Tahlgott, C. Personal communication, 25 June 2013. Former Head of the planning department, Munich, Germany.

[15] Sijmons, D., Mind the gap (Chapter 2). Rising waters, shifting lands, eds. C. Girot \& F. Rossano, GTA: Zurich, pp. 9-12, 2012. 